\title{
INTEGRATED MARKETING COMMUNICATIONS IN SUSTAINABLE BUSINESS
}

\author{
Santa Bormane \\ University of Latvia, Latvia
}

\begin{abstract}
Business sustainability hinges on authorities' action, cooperation and willingness to protect nature and natural resources, but they also have to meet the economic needs and cultivate the economic opportunities, whilst also satisfying the social needs and building a fair relationship among the different social groups. One of the ways to develop a sustainable business is integrated marketing communications. When using integrated marketing communications, businesses - notably food producers and retailers - need to focus on the education of consumers, the ecological performance and impact of products on the environment and human health, thus contributing to a sustainable development of Latvia's economy overall. The aim of the research is to evaluate the prospects of development of Latvian food retail chains through the use of integrated marketing communication tools for sustainable business. The following scientific research methods are used in the research study: analytical, comparative, graphical, statistical, observatory and interrogative. The research focuses on the Latvian food retail sector, the subject being Latvian food retail chains, with leading specialists from all Latvian food retail chains surveyed. The research confirmed the hypothesis of the positive influence of the use of IMC tools for sustainability upon demand at Latvian food retail chains, its contribution to the formation of public opinion on the importance of preservation of the environment, the enhancement of consumer awareness, the promotion of corporate social responsibility for consumer health, ecological products overall, and the role and contribution of a green economy to a sustainable development of the national economy as a whole. The author has defined IMC for sustainability, developed and classified IMC tools for sustainability, and drawn up an IMC model for sustainability. The results of the research are of both theoretical and practical value.
\end{abstract}

Keywords: integrated marketing communication model, integrated marketing communication tools for sustainability, sustainability, sustainable development; sustainable marketing.

\section{Introduction}

Business sustainability hinges on authorities' action, cooperation and willingness to protect nature and natural resources, but they also have to meet the economic needs and cultivate the economic opportunities, whilst also satisfying the social needs and building a fair relationship among the different social groups. One of the ways to develop a sustainable business is integrated marketing communications. When using integrated marketing communications, businesses - notably food producers and retailers - need to focus on the education 
of consumers, the ecological performance and impact of products on the environment and human health, thus contributing to a sustainable development of Latvia's economy overall.

The aim of the research is to evaluate the prospects of development of Latvian food retail chains through the use of integrated marketing communications for sustainable business. In order to achieve the goal, the following research tasks were put forward: 1) to define IMC for sustainability, 2) to develop IMC tools for sustainability, 3) to classify IMC tools into groups, 4) to draw up a questionnaire for experts, 5) to survey the leading specialists at Latvian food retail chains in order to assess the impact of IMC tools for sustainability upon demand, economic development, social responsibility and environment preservation, and whether Latvian food retail chains intend to apply particular IMC tools for sustainability in their marketing strategy within the next 3 years, 6) to collect and assess the results of the expert survey, 7) to draw conclusions based on the expert survey, and 8) to draw up an IMC model for sustainability. The object of the research is Latvian food retail chains, and the subject of the research is IMC tools for sustainability.

The following scientific research methods are used in the research study: analytical, comparative, graphical, statistical, observatory and interrogative. The research focuses on the Latvian food retail sector, the object being Latvian food retail chains, with leading specialists from all Latvian food retail chains surveyed.

\section{Integrated marketing communication in a concept of sustainable marketing}

With the rapid growth of population, development of technologies and change in economic relationships, and owing to such issues as poverty, preservation of ecosystem, shortage of food and water, climate change etc., sustainability is becoming an increasingly topical matter (Martin \& Schouten, 2012).

As the current society is interested in the preservation of the environment, the promotion of a healthy lifestyle and other matters of public welfare, businesses, using a sustainable marketing strategy, need to offer products with consideration of preservation and future sufficiency of natural resources. Through taking social responsibility and using marketing communications, they need to focus on the education of consumers on the ecologic performance and impact of products on the human health, their composition and options of purchase, storage, use and utilisation, prioritising national production and thus supporting the domestic market and contributing to sustainable development of Latvia's economy overall (Bormane et al., 2017). 
The author's previous research has confirmed that businesses need to adapt their assortment of goods and services to the changeable needs of consumers, the general public attitude, and the legislation. They are frequently able to negotiate with various stakeholders to achieve changes in the overall consumption of goods/services instead of merely changing their corporate activity.” (Bormane \& Praude, 2013).

It follows from the above that sustainability depends not only on the process where a product is created, but also on contributions to the future through improving the present situation. This is a profoundly integrated concept, not limited to environmental and ecological aspects, but relevant to social, economic and cultural development issues as well. A company should implement sustainability as satisfaction of the current needs of consumers and the society on the basis of market opportunities, corporate resources, communication with consumers, with the preservation and development of environmental resources kept in mind to meet the needs of future generations (Bormane \& Praude, 2013).

When it comes to different dimensions of sustainable business development, Boons (2013), Lüdeke-Freund (2013) and Ciemleja (2010) mention business management tools both directly and indirectly related to marketing, such as offer value and interaction with customers (Boons \& Lüdeke-Freund, 2013), production process, customer relations management and the selling process. (Ciemleja, 2010). Consequently, marketing is a key component of the business management system in the context of sustainable development. Furthermore, since the promotion of sustainable development sees merging and combination of various activities and elements of marketing communication, one can conclude that it is the IMC elements that matter in a successful sustainable business management system, because "integrated marketing communications unite all marketing communication activities" (Pickton \& Broderick, 2005) and, as argued by Pickton (2005) and Broderick (2005), "are a customer relation management process that raises the brand value.” (Pickton \& Broderick, 2005)

According to Laura Illia (2012) and John M. T. Balmer (2012), the main function and form of marketing and the essence of the entire traditional marketing mix (4P) is business communication. For instance, in respect of product promotion it is crucial to understand how to integrate all messages in a single strategy with support to all IMC activities. This context also requires a thorough understanding of consumers' values and proximity to the company's brand, as the communication and identity of consumers and suppliers relates to the company's general communication and identity. The authors have noted the importance of considering the integration of both horizontal and vertical communication methods and distinguished the following links: 1) primary communication (products, services, management, personnel and corporate behaviour); 2) secondary communication (depending on the form of communication); 3) 
tertiary communication (depending on third parties, such as comments by competitors and the media). 4) All communications interact among the organisation, the organisation's identity and reputation, so the entire communication process, including IMC, affects the stakeholder relationship, including political, economic, ethnical, social and technological aspects (Illia \& Balmer, 2012).

Reid (2012) argues that the essence of IMC is: 1) to conduct an analysis of customers and stakeholders to identify the perception of value and the best way of interaction; 2) ensure the consistency of all messages sent by brand sponsors (e.g., the company) and work on strengthening the brand value; 3) to create and manage a multi-functional approach to the planning of marketing communications; 4) to use new technologies (e.g., databases) to understand the customer-brand relationship; 5) learn from the analysis, planning and implementation of communications to allocate resources more efficiently and profitably (Reid, 2012).

A peculiar view on IMC is proposed by Finne (2012) and Strandvik (2012) who introduced a new concept of IMC theory - invisible communication which includes non-existence of communication: planned and unplanned. Planned and controlled communication is visible, but communication may also be unplanned and is then identified as invisible. There are values and forms created, but no dialogues take place (Finne \& Standvik, 2012).

Given the above and based on the scientific literature on the marketing communication process and IMC, the author finds that there are four main elements of the communication process - sender, message, channel and recipient. The IMC process is very similar to that of marketing communication, yet IMC include an approach that envisages conveying one consistent message to the recipient through organisational promotional activities which may simultaneously encompass a broad range of media.

Duralia (2014), too, in reference to Danciu (2006), has stressed that the competitive marketing strategy of businesses will be sustainable if: 1) based on at least one environmentally sustainable advantage; 2) aimed towards ecological customers and attractive to them; 3) capable of counteracting environmentfriendly pressures by competitors; 4) improves the company's market position as an environmental factor (Duralia, 2014).

The use of IMC is constantly developing and the opportunities given by this process become increasingly topical for small and large businesses alike. The existing models of IMC enable to understand the IMC process, yet there is a lack of guidelines, a single model, a classification of tools, which businesses could follow to implement IMC systematically in the context of sustainable development and to optimise its processes. The author believes that the wellknown IMC models are not enough for reaching the marketing targets, as the tools 
applied in the IMC processes, existing in the scientific literature for now, have not been sufficiently classified and described and do not include the basic conditions of sustainable development - public wellbeing, environment preservation, and economic development.

\section{A study of the conceptual approach of integrated marketing communications for sustainable development}

Concurring in essence with the conclusions that the development of the sustainable marketing concept makes businesses think of sustainability and its inclusion in their tactical marketing targets, the author put forward a hypothesis that the use of IMC tools for sustainability has a positive impact on demand at food retail chains, contributes to the formation of public opinion on the importance of preservation of the environment, the enhancement of consumer awareness, the promotion of corporate social responsibility for consumer health, ecological products overall, and the role and contribution of a green economy to a sustainable development of the national economy as a whole. In order to confirm or reject the hypothesis, the author conducted research on IMC for sustainability at Latvian food retail chains.

Given that the present market and consumers require a new way of communication that covers sustainability goals - environment preservation, social responsibility and economic development -, this research is not limited to the classic IMC aimed towards marketing activities and buyer behaviour in the market. The author has developed and classified IMC tools for sustainability, first defining IMC for sustainability, surveyed the leading specialists at Latvian food retail chains with a view to assess the impact of IMC for sustainability on demand, economic development, social responsibility and environment preservation and whether Latvian food retail chains intend to apply particular IMC tools for sustainability in their marketing strategy within the next 3 years, as well as drawn up an IMC model for sustainability based on the results of the expert survey.

The expert survey was distributed to leading specialists of all Latvian food retail chains. The expert survey was held in 2017, and the MS Excel software was used for data processing and analysis. The IMC tools for sustainability developed, collected and classified by the author are shown in Table 1; a summary of the results of the expert survey with the most popular IMC tools for sustainability with a positive impact on demand and sustainable development is presented in Figure 1, and the IMC model for sustainability drawn up by the author on the basis of the results of the research is rendered in Figure 2.

As mentioned, before presenting IMC tools for sustainability in detail one needs to define IMC for sustainability. The author proposes the following definition: Integrated marketing communication for sustainability (IMC S) is 
the implementation of marketing activities by integrating opportunities of public welfare, environment preservation and balanced economic development with a view to increase the consumption value of a product or service through the company's communication with market participants using distribution channels.

The author further explains that, under the definition, the product consumption value is not only the product's economic value measured in money, but also the consumption value given by the availability of information to consumers when choosing the product, an informed choice of the product, a purchase out of necessity, as well as the consumer's knowledge on its functions, use, utilisation and other consumption-related matters. In the author's view, such a product consumption value would encourage a sustainable management - public thinking and action.

A marketing that fits in sustainable economic development may be deemed sustainable marketing. Hence, the IMC included in the traditional marketing communication of businesses with their consumers may as well serve as a tool for sustainability. Businesses may work with various stakeholders to achieve changes in the overall consumption of goods or services instead of merely changing their corporate activity. For instance, when working on product packaging, they may choose among a variety of materials and contemporary advancements. Likewise, when working on product promotion, they may promote sustainable consumption etc. IMC tools for sustainability may serve as market tools in the sustainable development of the country overall.

Latvia's Sustainable Development Strategy “Latvija 2030” sets out priority long-term directions, such as 1) creation of market instruments that would enable a market in ecosystem services and products and improve the ecological efficiency of the country's economy, help attract private funding for the preservation and regeneration of the natural capital; 2) promotion of healthy lifestyle - the reduction of biodiversity and the climate changes are largely driven by households as final consumers. The economic activity and excessive consumption by people result in an increasing release of greenhouse gases into the atmosphere and depletion of natural resources. By promoting involvement in the preservation of ecosystems it is possible to evolve into a society that respects the natural capital etc. (Latvija 2030). For instance, one of the solutions put forward for the promotion of a sustainable lifestyle is certification of sustainable products (Latvija 2030).

Based on the above, the author believes that demand is nowadays affected by various factors, but sustainable business development in the traditional IMC with consumers requires tools that facilitate the accomplishment of sustainability goals. In Table 1, the author has developed, aggregated and classified IMC tools for sustainability ( 80 pcs) and divided them into 8 main groups. They have been 
categorised based on the following principle: 1) management IMC tools for sustainability (8 pcs) - includes a marketing communication management system, focusing on the promotion of sustainable, ecological, Latvian-made products; 2) product-related IMC tools for sustainability (14 pcs) - includes tools that facilitate the availability of ecological Latvian-made products by supporting domestic production and agriculture and educating consumers on healthiness, ecology, packaging, product usage, utilisation options etc., 3) pricerelated IMC tools for sustainability (5 pcs) - primarily includes the pricing policy having regard to the sustainability goals, aimed towards boosting the consumption of domestic-made, ecological and sustainable products or introducing new products into the market; 4) promotion-related IMC tools for sustainability (28 pcs) - deal with the physical availability of goods in stores and the availability of information on sustainable, healthy, ecological, domestic-made products; 5) digital promotion-related IMC tools for sustainability (12 pcs) enable extensive communication options among consumers, with businesses able to convey information to the public in a brief form, save resources and time, build a positive image, while for consumers there is an opportunity to belong to a social group, share opinions, get actively involved, save time, do comparative shopping etc.; 6) staff professionalism- and selling-related IMC tools for sustainability ( 2 pcs) - generates feedback between consumers and the company and promotes sustainable consumption, substantially affects the buyer behaviour at such stages as information searching and consideration of alternatives, buying decision, and buying; 7) corporate identity-related IMC tools for sustainability (6 pcs) - key to covering large social groups, enhancing the public's awareness, and changing its routine thinking and action. Investments in scientific research or conferences, education, instructional literature as IMC tools for sustainability pave the way for new approaches and methods, contribute to the scientific development, form the theoretical basis of further practical business; 8) geographic placement- and technology-related IMK tools for sustainability (5 pcs) - for the mitigation of risk, the testing of product quality, the introduction of new products into the market etc.

A full list of the IMC tools for sustainability developed, aggregated and classified by the author is presented in Table 1 .

IMC tools for sustainability enable businesses to generate feedback because through marketing communications consumers receive information from the company on the products or services being offered, also in the context of sustainability - the preservation of the environment and the stimulation of economic growth and public wellbeing in Latvia. 
Table 1 IMC tools for sustainability

(source: IMC tools for sustainability developed, aggregated and classified by the author)

\begin{tabular}{|c|c|}
\hline No. & Marketing communication tools for sustainability \\
\hline 1. & Management tools for sustainability \\
\hline 1.1. & Sustainability targets in the company’s informational resources \\
\hline 1.2. & Strategic planning of marketing communications for sustainability \\
\hline 1.3. & Inclusion of ecological product in tactical sales-inducing activities \\
\hline 1.4. & Company's participation in social responsibility for consumer health \\
\hline 1.5. & Company's participation in building public opinion on environment preservation \\
\hline 1.6. & Raising public awareness of ecological products in general \\
\hline 1.7. & Marketing staff training on sustainability, sustainable products \\
\hline 1.8. & $\begin{array}{l}\text { Customer loyalty programmes driven towards boosting sales of sustainable ecological } \\
\text { Latvian-made products and consumers who buy ecological products regularly }\end{array}$ \\
\hline 2. & Product-related tools for sustainability \\
\hline 2.1. & Proportion of ecological products on offer \\
\hline 2.2. & Proportion of Latvian-made products on offer \\
\hline 2.3. & $\begin{array}{l}\text { Proportion of genetically modified products or products containing genetically } \\
\text { modified food ingredients on offer }\end{array}$ \\
\hline 2.4. & Proportion of import products on offer \\
\hline 2.5. & $\begin{array}{l}\text { Proportion of products with environment-friendly packaging (with quick natural } \\
\text { decomposition) on offer }\end{array}$ \\
\hline 2.6. & Proportion of products with recycled packaging on offer \\
\hline 2.7. & Product packaging design promoting consumer awareness of sustainability \\
\hline 2.8. & Information on product labels promoting consumer awareness of sustainability \\
\hline 2.9. & Information provided by product marking on product healthiness and nutritional value \\
\hline 2.10. & $\begin{array}{l}\text { Information provided by product marking on packaging recycling and utilisation } \\
\text { options }\end{array}$ \\
\hline 2.11. & Best before dates of import products \\
\hline 2.12. & Best before dates of Latvian-made products \\
\hline 2.13. & Proportion of products with long best before period in assortment \\
\hline 2.14. & Proportion of products with relatively short best before period in assortment \\
\hline 3. & Price-related tools for sustainability \\
\hline 3.1. & Pricing policy making for sustainability \\
\hline 3.2 . & Price discounts on ecological products \\
\hline 3.3. & Price discounts on Latvia-made products \\
\hline 3.4. & Price discounts on products with environment-friendly packaging \\
\hline 3.5 . & Sales promotion activities for ecological products \\
\hline 4. & Promotion-related tools for sustainability \\
\hline 4.1. & Product quantity and availability to buyers in store during evening hours \\
\hline 4.2. & Position of Latvian-made products in stores \\
\hline 4.3. & Position of own-brand products in stores \\
\hline 4.4. & Position of import products in stores \\
\hline 4.5. & $\begin{array}{l}\text { Position of genetically modified products (or products containing genetically } \\
\text { modified food ingredients) in stores }\end{array}$ \\
\hline
\end{tabular}


SOCIETY. INTEGRATION. EDUCATION

Proceedings of the International Scientific Conference. Volume VI, May $25^{\text {th }}-26^{\text {th }}, 2018.80-96$

\begin{tabular}{|c|c|}
\hline 4.6. & $\begin{array}{l}\text { Informational messages at eye height on presence of genetically modified organisms } \\
\text { in food }\end{array}$ \\
\hline 4.7. & Informational messages at eye height on presence of ecological products in store \\
\hline 4.8. & $\begin{array}{l}\text { Informational messages at eye height on availability of lactose-free and gluten-free } \\
\text { products }\end{array}$ \\
\hline 4.9. & Informational messages on vegan products (without ingredients of animal origin) \\
\hline 4.10. & $\begin{array}{l}\text { Company's information online, incl. the website, on product composition and impact } \\
\text { on human health }\end{array}$ \\
\hline 4.11. & Company's information online, incl. the website, on recycling of product packaging \\
\hline 4.12 & $\begin{array}{l}\text { Company's information online, incl. the website, on impact of product packaging and } \\
\text { waste volume on public health and environment preservation }\end{array}$ \\
\hline 4.13. & Outdoor advertisements on product quality, composition and impact on human health \\
\hline 4.14. & $\begin{array}{l}\text { Outdoor advertisements on impact of product packaging and waste on human health, } \\
\text { environmental harm }\end{array}$ \\
\hline 4.15. & Outdoor advertisements on product storage, packaging recycling and utilisation etc. \\
\hline 4.16. & $\begin{array}{l}\text { Advertisements in mass media (TV, radio, press etc.) on product quality, composition } \\
\text { and impact on human health }\end{array}$ \\
\hline 4.17. & $\begin{array}{l}\text { Advertisements in mass media (TV, radio, press etc.) on product storage, packaging } \\
\text { recycling and utilisation }\end{array}$ \\
\hline 4.18. & $\begin{array}{l}\text { Advertisement stands (at shops, exhibitions) on product quality, composition and } \\
\text { impact on human health }\end{array}$ \\
\hline 4.19. & Advertisement stands on product storage, packaging recycling and utilisation \\
\hline 4.20. & $\begin{array}{l}\text { Advertisement stands on harm of product packaging to environment and human } \\
\text { health }\end{array}$ \\
\hline 4.21. & $\begin{array}{l}\text { Company's special newspapers, catalogues on product quality, composition and } \\
\text { impact on human health }\end{array}$ \\
\hline 4.22. & $\begin{array}{l}\text { Company's special newspapers, catalogues on product storage, packaging recycling } \\
\text { and utilisation }\end{array}$ \\
\hline 4.23. & $\begin{array}{l}\text { Company' special newspapers, catalogues on environmental harm of products and } \\
\text { packaging }\end{array}$ \\
\hline 4.24. & $\begin{array}{l}\text { Competitions, lotteries, coupons, souvenirs to promote sales of environment-friendly } \\
\text { products }\end{array}$ \\
\hline 4.25 . & Competitions, lotteries, coupons, souvenirs to promote sales of ecological products \\
\hline 4.26. & Gifts for purchase (ecological products) \\
\hline 4.27. & $\begin{array}{l}\text { Salesman's advice on ecological performance of products, harmlessness of packaging } \\
\text { and its utilisation options etc. }\end{array}$ \\
\hline 4.28. & In-store degustations of ecological products \\
\hline 5. & Digital promotion-specific tools for sustainability \\
\hline 5.1. & $\begin{array}{l}\text { Structure of information available on the company's website with ecological and } \\
\text { Latvian-made products singled out }\end{array}$ \\
\hline 5.2. & Information on the company’s website on ecological products available in stores \\
\hline 5.3. & Information on the company's website on Latvian-made products available in stores \\
\hline 5.4 . & Mobile app with information on ecological products available in stores \\
\hline 5.5 . & Mobile app with information on Latvian-made products available in stores \\
\hline 5.6. & $\begin{array}{l}\text { Information within product barcode on disposal and recycling of product packaging, } \\
\text { impact of composition and quality on health, pictures on general application }\end{array}$ \\
\hline
\end{tabular}




\begin{tabular}{|l|l|}
\hline 5.7. & $\begin{array}{l}\text { Formation of social groups on social media for consumers who regularly buy } \\
\text { ecological products }\end{array}$ \\
\hline 5.8. & $\begin{array}{l}\text { Involvement of consumers in popularisation, evaluation, promotion of the company's } \\
\text { products on the website, social media etc. (reward for consumer activities - game } \\
\text { system) }\end{array}$ \\
\hline 5.9. & Mass involvement in new product creation \\
\hline 5.10. & $\begin{array}{l}\text { System of game elements linked to brand loyalty programme to promote sales of } \\
\text { ecological products (points, discounts, gifts, status) }\end{array}$ \\
\hline 5.11. & Linkage of the loyalty card to payment options, account replenishment options \\
\hline 5.12. & Linkage of the loyalty card to budget planning options \\
\hline 6. & Staff professionalism- and selling-related tools for sustainability \\
\hline 6.1. & $\begin{array}{l}\text { Staff training, workshops etc. on composition and health impact of ecological } \\
\text { products, on recycling and utilisation of food packaging }\end{array}$ \\
\hline 6.2. & $\begin{array}{l}\text { Integration of game elements in employee motivation system (rewards for sales } \\
\text { increase, customer appreciation etc.) }\end{array}$ \\
\hline 7. & Corporate identity-related tools for sustainability \\
\hline 7.1. & $\begin{array}{l}\text { Charity initiatives in the context of sustainable development (environment } \\
\text { preservation, public health, promotion of sales of Latvian-made products) }\end{array}$ \\
\hline 7.2. & Investment in scientific research \\
\hline 7.3. & Support and contribution to conferences, education, instructional literature \\
\hline 7.4. & Charity initiatives in culture, cinema, art etc. \\
\hline 7.5. & Investment in new product creation \\
\hline 7.6. & $\begin{array}{l}\text { Aid to social groups - large families, disabled people, orphans etc. (e.g., further } \\
\text { discounts, food baskets) }\end{array}$ \\
\hline 8. & Geographic placement- and technology-related tools for sustainability \\
\hline 8.1. & Product quality testing at a certified licensed laboratory (service for consumers) \\
\hline 8.2. & $\begin{array}{l}\text { Certified licensed laboratory (for assessment of hazardous, poisonous, radioactive } \\
\text { substances and/or food quality, incl. for mitigation of the company's risks) }\end{array}$ \\
\hline 8.3. & Availability of environment-friendly shopping bag materials \\
\hline 8.4. & Waste sorting facilities \\
\hline 8.5. & Greenery within shop premises \\
\hline
\end{tabular}

In order to assess the impact of the IMC tools for sustainability developed by the author upon demand at food retail chains, economic development, social responsibility and environment preservation and to find out whether Latvian food retail chains intend to apply the said IMC tools for sustainability in their marketing strategy within the next 3 years, the author prepared a questionnaire and in 2017 surveyed the leading specialists of Latvian food retail chains. The MS Excel software was used for data processing and analysis.

The experts were asked to reveal whether in the next 3 years the Latvian food retail chains intend to use IMC tools for sustainability in their marketing strategy and rate how the use of IMC tools for sustainability would affect demand, economic development, social responsibility and environment preservation by the following scale: $N$ - the sustainable marketing communication in question does 
not exist; -1 - the sustainable marketing communication in question reduces demand, its use will harm the economic and social development of the country and the preservation of the environment; 0 - the sustainable marketing communication in question does not affect demand, its use will not affect the economic and social development of the country and the preservation of the environment; 1 - the sustainable marketing communication in question slightly increases demand, its use will have a positive effect on the economic and social development of the country and the preservation of the environment; 2 - the sustainable marketing communication in question substantially increases demand, its use will have a substantial positive effect on the economic and social development of the country and the preservation of the environment.

Based on the results of the expert survey (see Figure 1), the author has visually represented the most popular IMC tools for sustainability from among all the 8 groups of IMC tools for sustainability that 1) increase demand at Latvian food retail chains; 2) would have a positive effect on economic development, social responsibility and environment preservation if used in a marketing strategy; 3) are planned for introduction by Latvian food retail chains in their marketing strategy within the next 3 years (summary of ratings - arithmetic mean, medians).

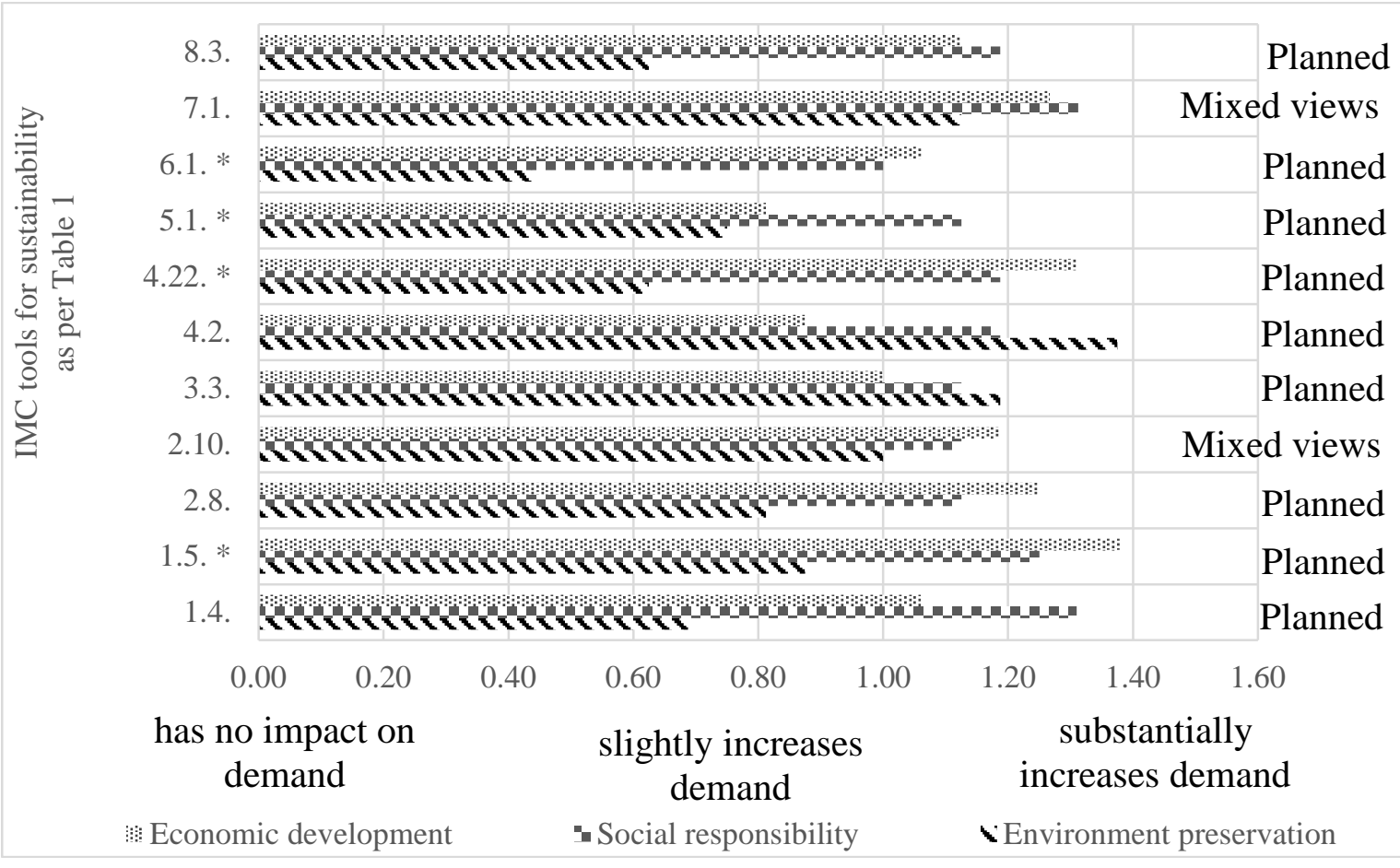

Figure 1. Main IMC tools for sustainability with positive impact on demand at food retail chains, conducive to sustainable development (source: figure created by the author in MS Excel based on the summary (arithmetic mean) of the results of the expert survey) 
The summary of the expert survey leads of a conclusion that businesses rate the use of IMC tools for sustainability as conducive to economic development, environment preservation and social responsibility, and suggests that understanding of sustainability incites to take responsibility, to innovate, to generate new ideas to meet the interests of stakeholders as much as possible. Furthermore, Latvian food retail chains have deemed all the tools listed in Figure 1 as demand-increasing and intend to use those in their marketing strategy within the next 3 years, with the exception of charity initiatives in the context of sustainable development and information provided by product marking on product healthiness and nutritional value where the opinions are mixed.

The author presumes that part of Latvian food retail chains implement their marketing activities in campaigns rather than continuously. Sustainability goals, incl. charity initiatives in the context of sustainability, do not come to fruition and just some of the retail chains intend to include them in the marketing strategy. This stems from part of the companies being of foreign capital with a different market positioning: 1) some are leaders in low prices whose assortment primarily consists of affordable products (quality, composition and packaging much depends on their cost price), 2) others present themselves as sellers of premium products offering elite delicacies imported from different countries. Their marketing strategy may feature sustainability goals based on international practice.

As concerns information provided by product marking, the expert opinions are split because the implementation of this tool requires state support, regulatory framework etc.

The author points out that IMC tools for sustainability in Figure 1 (marked with *) - 6.1; 5.1; 4.22; 1.5 (as per Table 1) are new and not yet present in the marketing strategies of food retail chains, still the experts have recognised them as having a positive impact on economic development, social responsibility and environment preservation and intend to introduce those in their marketing strategies within the next 3 years.

The results of the expert survey served as the basis for the development of an IMC model for sustainability and the drafting of proposals (see Figure 2).

Sustainability issues increase the need for changes in demand, which, in turn, require changes in supply. Businesses need to change the approach in their marketing strategy from the classic communication to one that embodies not just sustainability goals, but an integrated systemic approach with a view to promote sustainable management, thinking and action; in other words - a sustainable lifestyle.

In Figure 2 the author presents an IMC conceptual model for sustainability schematically showing six levels or stages of communication. The $1^{\text {st }}$ level accommodates a company interested in communication with its consumers and a 
marketing strategy based on the marketing definitions in the scientific literature. The $2^{\text {nd }}$ level features the generally accepted marketing mix or 4P (product, price, promotion, place), which, under a successful marketing strategy and having regard to the organisational goals, enable to build a closer and more valuable relationship with customers. Both the scientific literature and practical business have proven that IMC may be used for effective communication with consumers, so in the $3^{\text {rd }}$ level there are the types of elements of marketing communication: advertising, sales promotion, public relations, personal selling and direct marketing, which help realise the company's integrated marketing communication for sustainability.

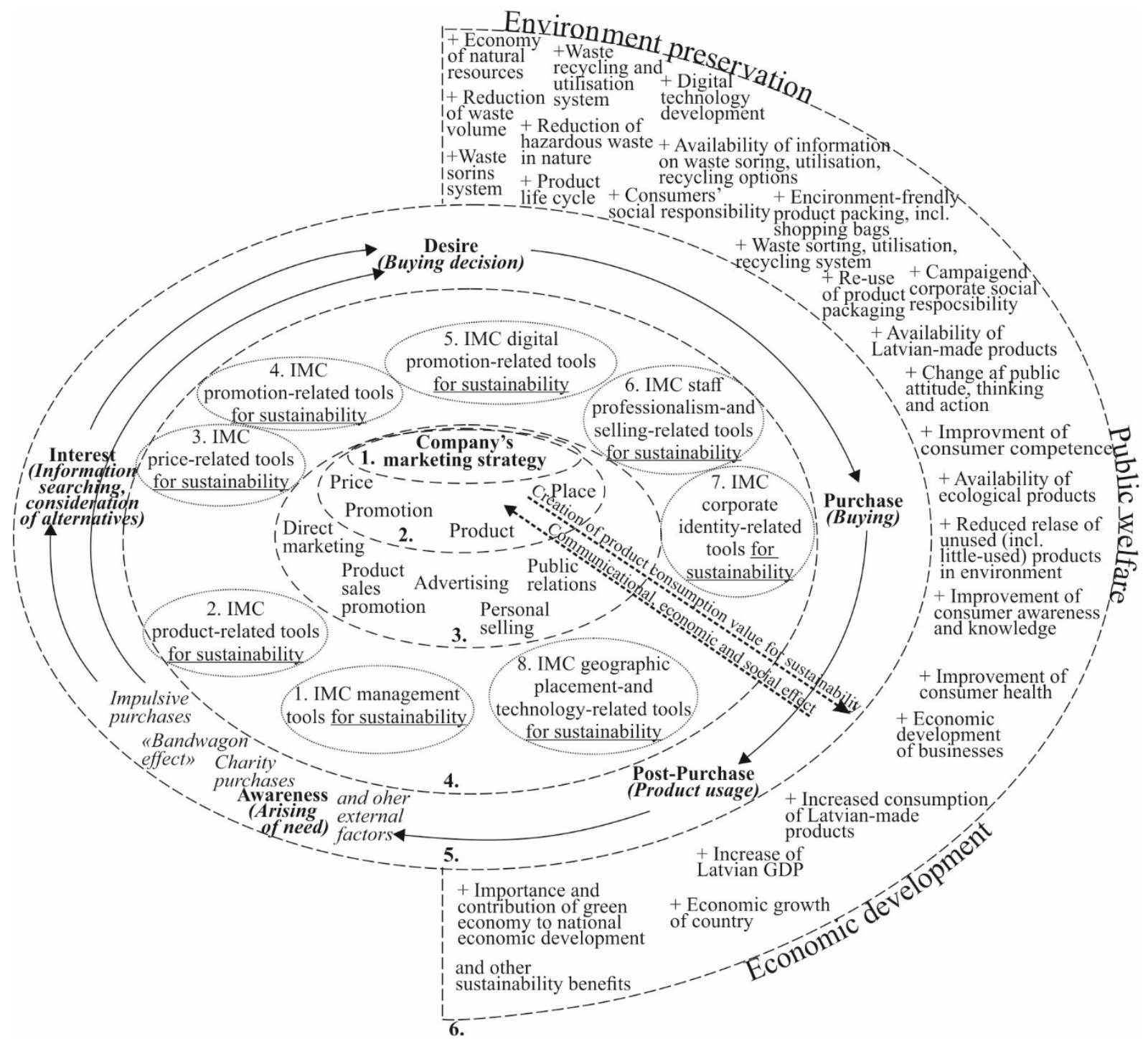

Figure 2. IMC model for sustainability

(source: IMC model for sustainability developed by the author) 
In order to reach the company's goals in communication with consumers, the IMC must be implemented through concrete, detailed, customer-oriented IMC tools for sustainability as developed by the author with a view to increase the consumption value of a product or service for sustainability - economic development, public wellbeing, and environment preservation. IMC for sustainability should be implemented through distribution channels (TV, radio, newspapers, the Internet and other communication channels). Hence, 4) level four of the model provides the groups of IMC tools for sustainability development by the author; 5) in level five the author has shown that through the said IMC tools for sustainability it is possible to reach the target audience and influence the buyers' behaviour. The creation of a product consumption value for sustainability is focused on such stages of buyer behaviour as buying and product usage because it is at these stages of buyer behaviour that the essence of sustainability comes into effect. The author stresses that buyers may also make impulsive purchases based on a variety of surrounding incentives or external factors, rather than out of necessity. In such a case it might never come to product usage as a stage of buyer behaviour, the product may end up in the trash bin and not contribute to environment preservation, social responsibility and economic development. Lastly, 6) level six of the model shows the benefits gained from the use of IMC tools for sustainability in a marketing strategy. For the company, the communicational, social and economic effect comes as feedback, but in the context of sustainable development there is the effect on environment preservation - saving of natural resources, reduction of waste, environmentfriendly product packaging etc.; social responsibility, which also raises the level of public wellbeing - improvement of consumer competence, availability of Latvian-made ecological products, improvement of consumer health, change of public opinion, thinking and action, incl. increased consumption of domesticmade products etc.

In communication with consumers (current and potential customers) through IMC, businesses can work continuously, rather than in campaigns, to accomplish sustainability goals - economic development, social responsibility, and environment preservation. Each sector certainly has peculiarities in product selling, service provision etc., yet there are also common market trends that apply to all industries. Hence, the author urges further market research, also covering product manufacturers that provide the product assortment. 


\section{Conclusions}

1. In a successful business management system, it is IMC as a business management tool that matters in building the offer value, interaction with customers, the production process, customer relations management, and the selling process in the context of sustainable development.

2. The improvement of business in terms of adherence to a sustainable marketing concept relates not only to the product assortment, quality, packaging and design, but also to distribution and promotion, thus contributing to the formation of public opinion on the importance of environment conservation, the raising of consumer awareness, the enhancement of corporate social responsibility for consumer health, ecological products overall, and the role and contribution of a green economy to the country's economy as a whole.

3. Businesses see the use of IMC tools for sustainability as conducive to economic development, environment preservation and social responsibility, which means that understanding of sustainability incites to take responsibility, to innovate, to generate new ideas to meet the interests of stakeholders as much as possible.

4. In order to achieve changes in the overall consumption of products whilst promoting a healthy lifestyle, businesses need to apply IMC tools for sustainability classified in 8 groups: management tools for sustainability, product-related tools for sustainability, price-related tools for sustainability, promotion-related tools for sustainability, digital promotion-related tools for sustainability, staff professionalism- and selling-related tools for sustainability, corporate identity-related tools for sustainability, and geographic placement- and technology-related tools for sustainability.

5. Market demand at Latvian food retail chains is increased by the IMC tools for sustainability which businesses intend to use in their marketing strategy within the next 3 years. This is suggested by businesses rating IMC tools for sustainability as having a positive impact on economic development, environment preservation, and social responsibility.

6. The application of IMC tools for sustainability enables businesses to generate a product consumption value focused on such stages of buyer behaviour as buying and product usage, since it is at these stages of buyer behaviour that the essence of sustainability comes into effect.

7. Making impulsive purchases based on surrounding incentives or external factors rather than out of necessity does not contribute to environment preservation, social responsibility and economic development, as there is a risk of not reaching the stage of product usage and the product ending up in the trash bin. 
8. Under the concept of sustainable marketing, by applying the model of IMC for sustainability, maintaining a systemic approach and using IMC tool for sustainability, businesses will promote sustainable consumption, raise the level of consumer awareness of the impact of a product and its production on the natural capital, expand the options of public participation, and foster a healthy lifestyle in general.

9. The research tasks put forward for the research study have been performed and the aim has been achieved. The theoretical and practical research confirm the initial hypothesis that the use of IMC tools for sustainability has a positive impact on market demand at Latvian food retail chains, contributes to the formation of public opinion on the importance of environment preservation, the enhancement of consumer awareness, corporate social responsibility for consumer health, ecological products in general and the role of a green economy in the sustainable development of the country's economy overall.

\section{References}

Boons, F., \& Lüdeke-Freund, F. (2013). Business models for sustainable innovation: state-ofthe-art and steps towards a research agenda. Journal of Cleaner Production, Volume 45, 9-19.

Bormane, S., \& Praude., V. (2013). Essence and importance of sustainable marketing in business. Humanities and Social Sciences Latvia, Latvijas Universitate, Volume 21, 41-51.

Bormane, S., Šķiltere, D., \& Batraga, A. (2017). Sustainability: economic, environmental and public issues. Marketing possibilities. Regional Formation and Development studies, 2135.

Ciemleja, G. (2010). The Sustainable Performance of Small and Medium-Sized Enterprises. Probems and Solutions., Summary of Doctoral Dissertation of Economics and Management, Riga Technical University.

Duralia, O. (2014). Applying sustainable marketing strategies - The key to obtaining competitive advantages On the industrial products market. Studies in Business and Economics no. 9 (3), 21-28;

Danciu, V. (2006). Marketing ecologic (Green Marketing). Economica, 28-32

Finne, A., \& Strandvik, T. (2012). Invisible communication: a challenge to established marketing communication. European Business Review, Volume 24, Issue 2, 120-133.

Illia, L., \& Balmer, J. M.T. (2012). Corporate communication and corporate marketing: Their nature, histories, differences and similarities. Corporate Communications: An International Journal, Volume 17, Issue 4, 415-433.

Martin, D., \& Schouten, J. (2012). Marketing in the Twenty-First Century, USA: Pearson Prentice Hall.

Pickton, D., \& Broderick, A. (2005). Integrated Marketing Communications, 2nd Edition, Pearson Education Limited. 
SOCIETY. INTEGRATION. EDUCATION

Proceedings of the International Scientific Conference. Volume VI, May $25^{\text {th }}-26^{\text {th }}, 2018.80-96$

Reid, M., (2012). Building Strong Brands Through the Management of Integrated Marketing Communications. International Journal of Marketing, Volume 41, 17-23

Latvija 2030. Retrieved from http://www.pkc.gov.lv/nap2020/latvija2030 [accessed on 08.02.2017] 